\title{
Evaluation of Mungbean (Vigna Radiata (L.) Wilczek) Genotypes on the Basis of Photosynthesis and Dry Matter Accumulation
}

\author{
M. A. HossAIN ${ }^{*}$, A. HAMID $^{2}$ \& M. A. KHALIQ ${ }^{3}$ \\ ${ }^{1}$ Soil Resource Development Institute, Mrittika Bhaban, Krishi Khamar Sarak, Dhaka-1215, Bangladesh \\ ${ }^{2 \& 3}$ Department of Agronomy, Bangabandhu Sheikh Mujibur Rahman Agricultural University, Salna, \\ Gazipur-1706, Bangladesh
}

\begin{abstract}
The study was carried out to evaluate six mungbean genotypes on the basis of photosynthesis and productivity under two levels of nitrogen. GK3 was found to have highest photosynthesis rate as well as the highest productivity among the six genotypes followed by VC6144A, PDM54 and IPSA25 irrespective of $N$ levels.
\end{abstract}

Key words: Mungbean, genotypes, photosynthesis.

\section{INTRODUCTION}

In the recent years mungbean has registered a steady growth in production as well as area under cultivation in Bangladesh. The crop is potentially useful in improving cropping systems, for it can be grown almost throughout the year. Mungbean can also tolerate drought to a great extent (Lawn and Ahn, 1984). In Bangladesh extensive cultivation of mungbean is constrained by strong competition with rice, particularly during wet season. The major reason lies in the fact that yields of mungbean are much lower compared with that of cereals. Although food legumes are important component of the diets in many Asian countries including Bangladesh and India, no important headway has so far been achieved in developing high yielding genotypes of any one of the 18 important legumes (Wallis and Byth 1998). Currently Bangladesh produces pulses that barely meet $30 \%$ of the total requirement. To close the protein gap for the burgeoning population it is necessary that production of pulses be increased. Photosynthesis has generally been considered to be the primary factor affecting the dry matter production in crop plants. The dry matter production and its subsequent conversion into economic yield are the result of a complex physiological process within plants. Manipulation of photosynthetic potentials has been practiced to increase crop productivity for a long time. In order to improve the production potential, selection of genotypes based on photosynthetic rates has been practiced in peas (Mahon and Hobbs 1987).

Genotypic variability in photosynthetic rate has been identified within several crop species (Babu et al. 1985; Mahon 1990; Biswas et al. 2001). Photosynthetic ability was evaluated on cultivars of mungbean and a significantly positive relationship was obtained between yield and photosynthetic rate (Srinivasan et al. 1985; Islam 1994). However, information available is not

*Corresponding author: SSO, SRDI, Mrittika Bhaban, Dhaka-1215, Bangladesh, Mobile: 01197060097, E-mail: altajolly@yahoo.com

(C) 2009 School of Agriculture and Rural Development, Bangladesh Open University, All rights reserved. 


\section{A. Hossain et al.}

sufficient in the field of photosynthesis and productivity in mungbean. Therefore the study was carried out to evaluate the mungbean genotypes from the aspects of photosynthesis and productivity.

\section{MATERIALS AND Methods}

The experiment was conducted in the Environmental Stress Research Site, Department of Agronomy, Bangabandhu Sheikh Mujibur Rahman Agricultural University and was laid out in Completely Randomised Design. Six genotypes viz. VC6153B, VC 6144A, GK 3, PDM 54, IPSA25 and VO $1443 A-G$ were the treatment variables for the experiment. The rows were arranged in north-south direction in a polyvinyl shed. The genotypes were raised under two levels of supplied nitrogen (High $\mathrm{N}-154 \mathrm{mg} / \mathrm{l}$ and Low $\mathrm{N}-34 \mathrm{mg} / \mathrm{l})$. Hoagland 3 solution: $\left(3.5 \mathrm{mM} \mathrm{Ca}\left(\mathrm{NO}_{3}\right)_{2}, 5 \mathrm{mM}\right.$ $\mathrm{KNO}_{3}, 1 \mathrm{mM} \mathrm{KH}_{2} \mathrm{PO}_{4}, 0.99 \mathrm{mM} \mathrm{MgSO}_{4}, 19 \mathrm{M} \mathrm{Fe}$-citrate and microelements made of $0.154 \mathrm{mM} \mathrm{N}$ (high $\mathrm{N}$ level-HN)) and Hoagland 1 solution: $\left(0.5 \mathrm{mM} \mathrm{Ca}\left(\mathrm{NO}_{3}\right)_{2}, 5 \mathrm{mM} \mathrm{K}_{2} \mathrm{SO}_{4}, 0.5 \mathrm{mM} \mathrm{Ca}\left(\mathrm{H}_{2} \mathrm{PO}_{4}\right)_{2}\right.$, $2 \mathrm{mM} \mathrm{CaSO}_{4}, 0.99 \mathrm{mM} \mathrm{MgSO}_{4}, 19 \mu \mathrm{M} \mathrm{Fe}_{2} \mathrm{O}_{3}$, and micro-nutrient) made of $0.3414 \mathrm{mM} \mathrm{N}$ (low N level-LN) were used as source for nitrogen.

The seeds of selected mungbean genotypes were sown on 13 April 2001 in vermiculite filled net bag. The net bag was inserted in the upper portion of $30 \mathrm{~cm}$ long perforated polyvinyl chloride (PVC) pipe sections. Three such PVC sections were tied to a triangular shaped bamboo frame so that the PVC sections can suspend in the nutrient solution. The seedlings were transferred in vessels (size- 20 liter) containing nutrient solutions (Hoagland 3 (high $\mathrm{N}-154 \mathrm{mg} / \mathrm{l}$ ) and Hoagland 1 (low N-34 mg/l) at 14 days after emergence (DAE) on 30 April 2001. Plants were supported in the upper portion by bamboo sticks. Some seedlings were replaced as they failed to survive under changed situation. Each vessel containing three seedlings of the concerned genotype was replicated thrice. One of the three plants from each vessel was harvested at 35 DAE i.e. 3 weeks after transferring in nutrient solution. Another was harvested at 49 DAE i.e. 5 weeks after transferring in nutrient solution. The remaining one was kept in the container up to maturity (c. 63 days). The $\mathrm{pH}$ of the solution was maintained at 6.5 by adding required amount of $4 \mathrm{~N} \mathrm{H}_{2} \mathrm{SO}_{4}$. The nutrient solution was changed twice in a week and was aerated continuously using air pump to maintain sufficient oxygen for root respiration and to provide solution mixing.

Photosynthesis was measured at vegetative, flowering, pod filling and maturity stage using fully expanded leaf (the third from the top) with a portable Photosynthesis System (Model: LiCOR6200) assembled with an Infra Red Gas Analyzer (IRGA) and data logger following the procedure described by Kubota and Hamid (1992). The size of clamp-on assimilation chamber of was kept fixed at $6.25 \mathrm{~cm}^{2}$. A metal halide lamp of $150 \mathrm{~W}$ was used to obtain a photosynthetic active radiation (PAR) of $1500 \mu \mathrm{mol} \mathrm{m} \mathrm{m}^{-1}$ during the measurement. Airflow through the chamber was $400 \mathrm{ml} \mathrm{min}^{-1}$; relative humidity (RH) of air supplied in the chamber was adjusted to $50 \%$ and chamber temperature was maintained at $30^{\circ} \mathrm{C} \pm 1$. Photosynthesis data was recorded from 9:30 to $3: 00 \mathrm{pm}$ in a steady-state condition after the leaf was placed in the chamber. Net photosynthesis rate $(\mathrm{Pn})$, leaf conductance (Cs), and other related parameters were available as computer output attached to the system. Leaf area was measured by an automatic leaf area meter (Model AAM 8, Hayashi Denko, Japan).

\section{Results AND Discussion}

\section{Dry matter accumulation}

Appreciable inter and intra-genotypic variations in dry matter accumulation were observed among mungbean genotypes throughout the growth phases under both high and low nitrogen level. Total dry matter (TDM) and plant organs DM at harvest varied significantly among genotypes (Figure $1 \& 2$ ).

All the treatments gave a mean value of plant dry mass of $38510 \mathrm{mg}$ and $45530 \mathrm{mg}$ under low $\mathrm{N}$ and high $\mathrm{N}$ level, respectively. Hence an increased nitrogen supply induced an increase in dry matter production by some 18 per cent that corresponds to the generally positive effects of this nutrient. 


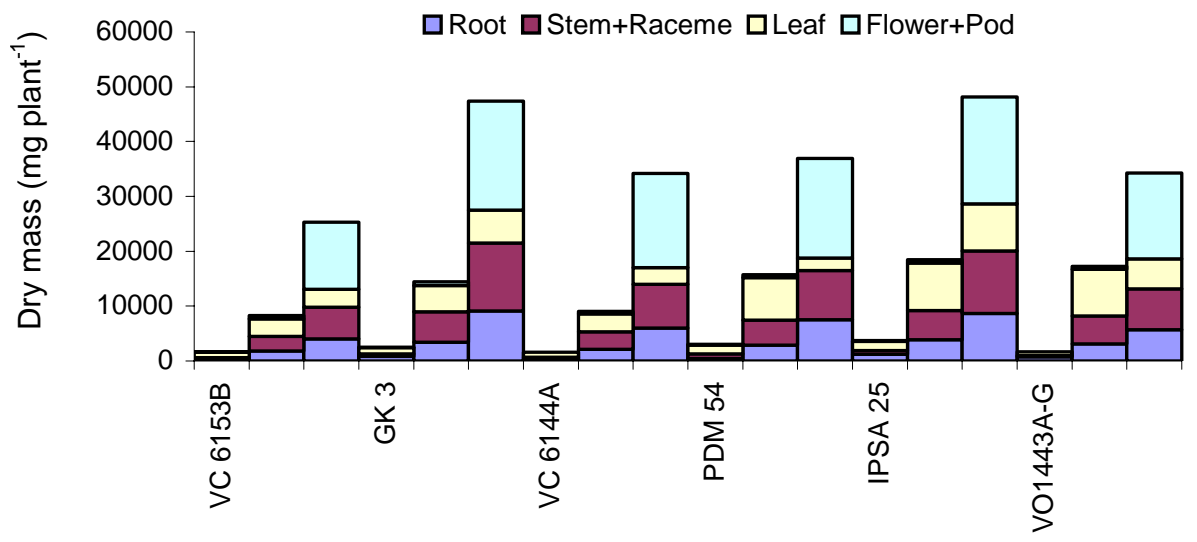

Figure 1. Variation in dry mass accumulation in plant parts among mungbean genotypes over time grown in solution under low nitrogen level

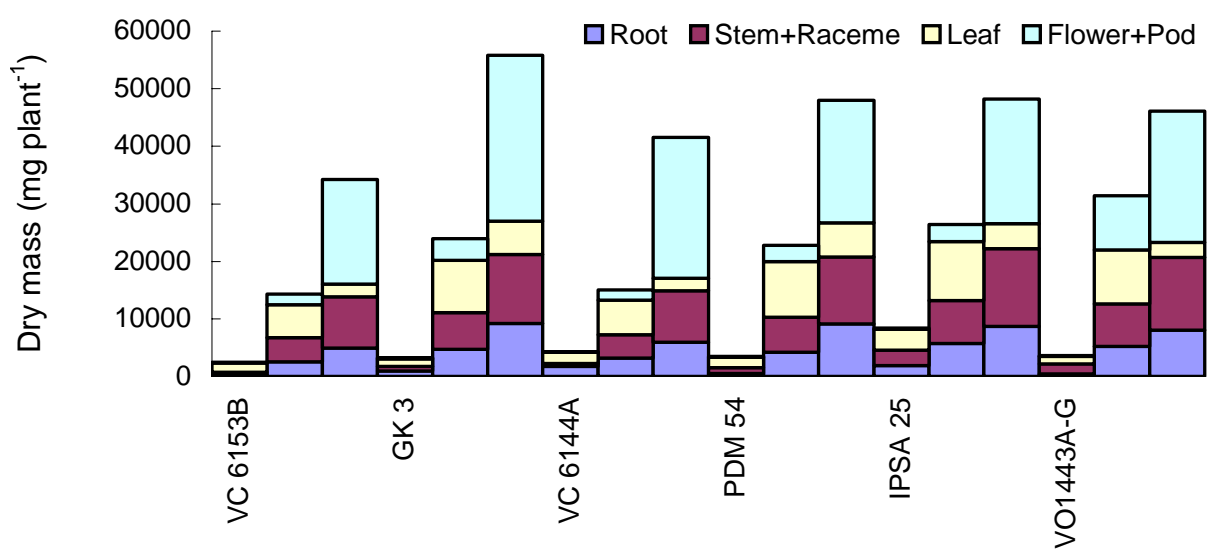

Figure 2. Variation in dry mass accumulation in plant parts among mungbean genotypes over time grown in solution under high nitrogen level

Under high $\mathrm{N}$ level high vigor genotypes attained higher growth rate and accumulated more dry matter than low vigor ones (except VC6153 and VC6144A). PDM 54 had more dry mass accumulation at the earlier phases till flowering (35 DAE) followed by VO 1443A-G and thereafter GK 3 took the lead and sustained till maturity. VC 6153B had consistently lower dry mass yield throughout the growth phases as its leaf senescence started earlier. But GK3 had consistently higher dry mass yield throughout the growth phases. Kuo et al. (1978) hypothesized that the genotypes having lower dry mass accumulation in the vegetative stage are lower yielder.

At low nitrogen supply, the maximum biomass of the low productive and high productive species differ significantly (Table 1 ). This is in agreement with data from the short-term experiments which show that species with an inherently high potential productivity have also in low-nutrient environments an equal or even a higher biomass production than species with inherently lowpotential productivity (Clark 1983; Bushby and Lawn 1992; Berendse 1994). Among the high growth genotypes, in GK3 higher percentage of dry mass was accumulated in seed at high $\mathrm{N}$ level comparative to that in low $\mathrm{N}$ level but it was higher than other genotypes in low $\mathrm{N}$ level. Among the low growth ones, in IPSA25 higher percentage of dry mass was accumulated in seed under high $\mathrm{N}$ level comparative to that in low $\mathrm{N}$ level. Relatively higher percentage of dry mass in IPSA25 was shifted to roots under low N level (Table 1). Moreover, GK3 out yielded all the genotypes in TDM, seed yield and total $\mathrm{N}$ uptake irrespective of $\mathrm{N}$-level. 
Table 1. Growth and yield attributes of mungbean genotypes at maturity as influenced by $\mathrm{N}$ levels grown in solution

\begin{tabular}{|c|c|c|c|c|c|c|c|c|c|c|c|}
\hline Genotypes & $\begin{array}{c}\mathrm{N}- \\
\text { level }\end{array}$ & $\begin{array}{c}\text { Root } \\
\text { wt. (g) }\end{array}$ & $\begin{array}{l}\text { Shoot } \\
\text { wt. (g) }\end{array}$ & $\begin{array}{c}\mathrm{LA} \\
(\mathrm{cm})\end{array}$ & $\begin{array}{c}\text { TDM } \\
(\mathrm{g})\end{array}$ & $\begin{array}{l}\text { Seed } \\
\text { pod }^{-1}\end{array}$ & $\begin{array}{c}\text { Seed } \\
\text { plant }^{-1}\end{array}$ & $\begin{array}{c}100 \\
\text { seed } \\
\text { wt. (g) }\end{array}$ & $\begin{array}{c}\text { Seed } \\
\text { yield } \\
\left(\mathrm{g} \text { plant }^{-1}\right)\end{array}$ & $\begin{array}{l}\text { Total } \\
\mathrm{N}(\%)\end{array}$ & $\begin{array}{c}\text { Total N } \\
\text { uptake } \\
\left(\mathrm{g} \mathrm{plant}^{-1}\right)\end{array}$ \\
\hline \multirow[t]{2}{*}{ VC6153B } & $\mathrm{N} 1^{*}$ & 4.01 & 21.29 & 410.91 & 25.30 & 7.8 & 250 & 5.14 & 5.54 & 2.31 & 0.58 \\
\hline & N2 & 4.91 & 29.32 & 355.48 & 34.24 & 8.3 & 400 & 5.70 & 12.74 & 2.64 & 0.90 \\
\hline \multirow[t]{2}{*}{ GK3 } & N1 & 7.55 & 41.00 & 532.40 & 48.55 & 7.7 & 454 & 4.53 & 15.89 & 2.30 & 1.12 \\
\hline & N2 & 9.20 & 46.58 & 780.80 & 55.78 & 7.9 & 488 & 4.94 & 21.43 & 2.87 & 1.60 \\
\hline \multirow[t]{2}{*}{ VC6144A } & N1 & 5.97 & 28.21 & 502.98 & 34.18 & 7.3 & 199 & 6.93 & 12.23 & 2.13 & 0.73 \\
\hline & N2 & 5.15 & 35.56 & 272.10 & 40.71 & 7.7 & 277 & 7.42 & 18.12 & 2.56 & 1.04 \\
\hline \multirow[t]{2}{*}{ PDM54 } & N1 & 9.15 & 33.97 & 766.78 & 43.12 & 8.7 & 388 & 3.83 & 13.26 & 1.96 & 0.84 \\
\hline & N2 & 7.27 & 38.38 & 643.43 & 45.61 & 8.8 & 463 & 3.87 & 16.16 & 2.23 & 1.02 \\
\hline \multirow[t]{2}{*}{ IPSA25 } & N1 & 8.65 & 37.80 & 1236.43 & 46.45 & 8.2 & 467 & 3.42 & 14.33 & 2.09 & 0.97 \\
\hline & $\mathrm{N} 2$ & 7.78 & 39.18 & 500.05 & 49.96 & 8.8 & 503 & 3.70 & 16.33 & 2.17 & 1.02 \\
\hline \multirow[t]{2}{*}{ V01443A-G } & N1 & 5.71 & 28.56 & 519.79 & 34.27 & 6.9 & 321 & 3.62 & 9.81 & 2.00 & 0.68 \\
\hline & N2 & 8.01 & 36.73 & 255.38 & 44.74 & 8.7 & 478 & 3.87 & 18.12 & 2.03 & 0.91 \\
\hline LSD 0 & & 0.422 & 1.897 & 47.90 & 7.7 & NS & 150 & 0.232 & 1.863 & 0.17 & 0.093 \\
\hline CV (\%) & & 6.53 & 5.80 & 9.10 & 18.02 & 15.86 & 41.18 & 5.23 & 12.58 & 5.78 & 7.13 \\
\hline
\end{tabular}

*Nitrogen level: N1 = 34ppm/l, N2 = 154ppm/l

\section{Variation in nitrogen content in different plant parts}

Nitrogen content differed among the plant parts and it fluctuates with the growth of the plant (Table 1). Nitrogen uptake was highest in GK3 irrespective of growth stages and $\mathrm{N}$ level. This indicates higher plasticity of the genotype to meet their nutrient demand under changed situation. Since the total amount of nitrogen of plant at harvesting was larger than that of pod filling stage, it is assumed that the major parts of nitrogen absorbed during the period of reproductive growth were highly translocated from leaf into grain.

In our present study it was observed that nitrogen content of the plant reduced with the aging of the plant. The percentage of nitrogen in different genotypes reduced in the order of $49 \mathrm{DAE}<63$ $\mathrm{DAE}<35 \mathrm{DAE}$. With the increase in dry matter the $\mathrm{N}$ content of the plant significantly reduced in different genotypes up to pod filling stage, irrespective of $\mathrm{N}$ levels. But at harvest the $\mathrm{N}$ content of the plant increased due to higher concentration of $N$ in seeds. Similar observation was made by Trung and Yoshida (1982) in mungbean grown in solution culture.

\section{Leaf photosynthesis}

The production of biomass and grain yield of pulse crops can largely be accounted for by photosynthesis during growth and maturation. It is generally considered that for high yield, high photosynthetic potentials are necessary. In mungbean, seed yield has been reported to be significantly related to the leaf photosynthetic rates of the crop at early pod development stage; whereas there was no significant relationship between the two parameters at vegetative stage (Srinivasan et al. 1985).

In the present study great differences in photosynthetic rates and its related parameters among the six genotypes were observed. Among all the parameters mesophyll conductance had the highest correlation with photosynthesis (Table 2). Leaf photosynthesis $(\mathrm{Pn})$ of six mungbean genotypes at different growth stages under two $\mathrm{N}$ levels are shown in Figures $3 \& 4$. It was observed that $\mathrm{Pn}$ was highest at flowering stage and then gradually decreased over time irrespective of genotypic difference and nitrogen level (Figure $3 \& 4$ ). Under optimal $\mathrm{N}$ level Pn rates ranged from $12.92 \mu \mathrm{mol} \mathrm{m} \mathrm{m}^{-2} \mathrm{~s}^{-1}$ (VO1443A-G) to $22.63 \mu \mathrm{mol} \mathrm{m} \mathrm{s}^{-1}$ (GK3), $15.26 \mu \mathrm{mol} \mathrm{m}^{-2} \mathrm{~s}^{-1}$ (VO1443A-G) to $41.42 \mu \mathrm{mol} \mathrm{m} \mathrm{s}^{-1}$ and $7.16 \mu \mathrm{mol} \mathrm{m}^{-2} \mathrm{~s}^{-1}$ (IPSA25) to18.60 $\mu \mathrm{mol} \mathrm{m}^{-2} \mathrm{~s}^{-1}$ (GK3) at vegetative, flowering and pod filling stage, respectively (Table 3). Under sub-optimal $\mathrm{N}$ level photosynthetic rate was lower than the optimal $\mathrm{N}$ level irrespective of genotype. Mesophyll conductance had the highest variability among the genotypes in different growth stages (Table 3). 
Table 2. $\mathrm{R}^{2}$ value of functional relationship between photosynthesis $(\mathrm{Pn})$ and mesophyll conductance $(\mathrm{Cm})$ among six mungbean genotypes

\begin{tabular}{lllc}
\hline \multicolumn{1}{c}{ Genotype } & N-level & Regression equation & $\mathrm{R}^{2}$-value \\
\hline VC6153B & N1 & $y=3.5952 x+3.383$ & 0.7260 \\
GK3 & N2 & $y=8.7974 x+3.6195$ & 0.3201 \\
& N1 & $y=8.6033 x+11.262$ & 0.9788 \\
VC6144A & N2 & $y=14.892 x-8.5062$ & 0.5202 \\
& N1 & $y=4.0366 x+12.694$ & 0.8206 \\
PDM54 & N2 & $y=7.1487 x+4.6487$ & 0.3256 \\
& N1 & $y=8.4232 x+1.7347$ & 0.9399 \\
IPSA25 & N2 & $y=4.052 x+4.6834$ & 0.5768 \\
& N1 & $y=10.294 x+0.9599$ & 0.9828 \\
VO1443A-G & N2 & $y=18.385 x-7.633$ & 0.7220 \\
& N1 & $y=4.726 x+5.7007$ & 0.6319 \\
& N2 & $y=2.1777 x+6.1767$ & 0.5195 \\
\hline
\end{tabular}

*Nitrogen level: N1-34ppm/l, N2-154ppm/l

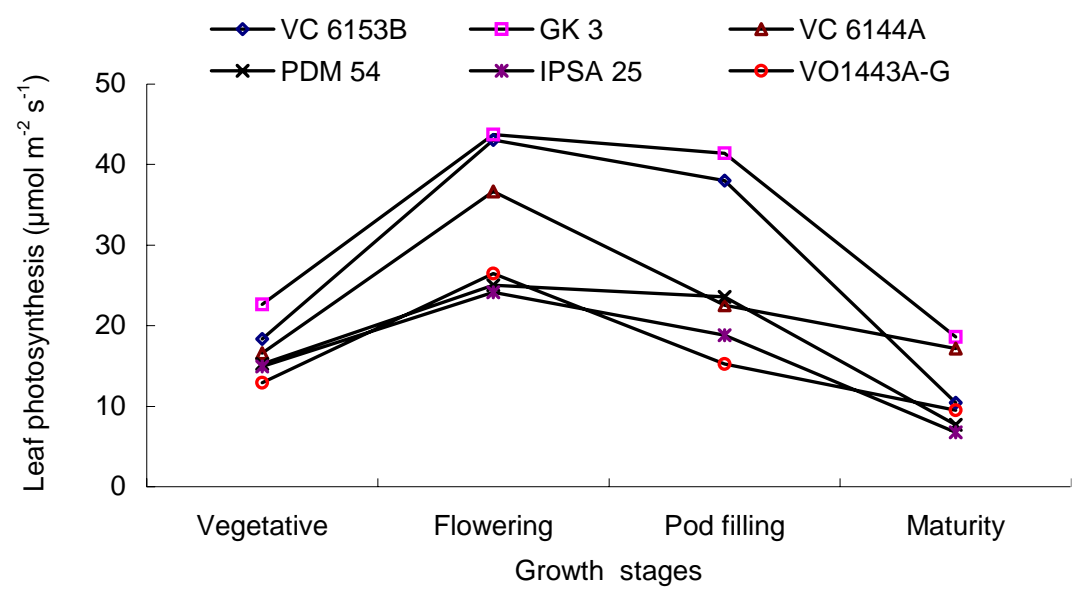

Figure 3. Influence of high $\mathrm{N}$ on leaf photosynthesis over time in mungbean genotypes grown in solution

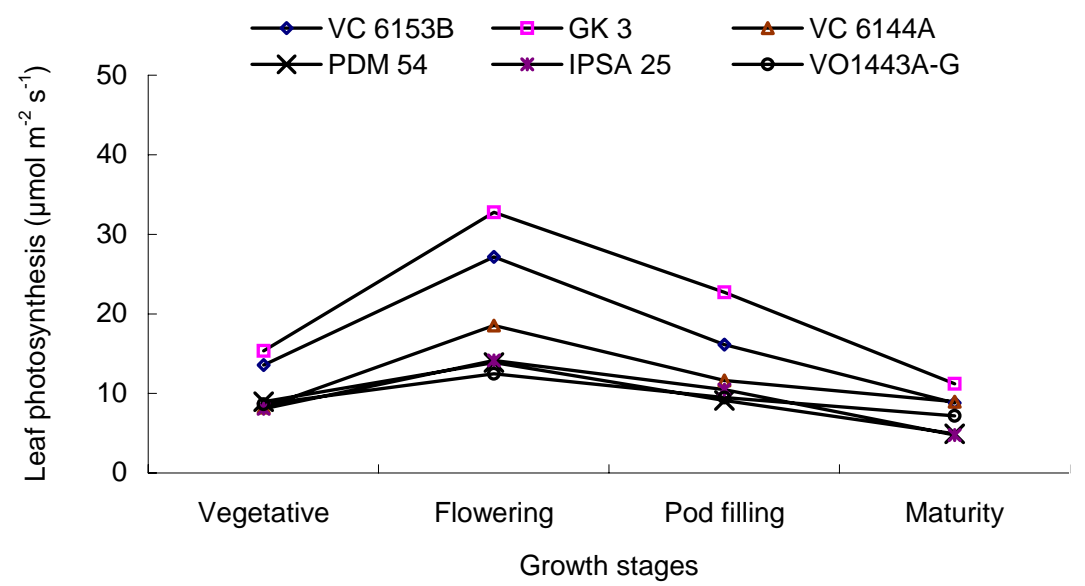

Figure 4. Influence of low $\mathrm{N}$ on leaf photosynthesis over time in mungbean genotypes grown in solution 
M. A. Hossain et al.

Table 3. Effect of $\mathbf{N}$ levels on leaf photosynthesis and its related parameters in mungbean genotypes

\begin{tabular}{|c|c|c|c|c|c|c|c|c|}
\hline \multirow{2}{*}{ Genotype } & \multicolumn{2}{|c|}{$\begin{array}{c}\mathrm{Pn} \\
\left.\left(\mu \mathrm{mol} \mathrm{m} \mathrm{m}^{-2}\right)^{-1}\right)\end{array}$} & \multicolumn{2}{|c|}{$\begin{array}{c}\mathrm{Cm} \\
\left(\mathrm{mol} \mathrm{m}^{-2} \mathrm{~s}^{-1}\right)\end{array}$} & \multicolumn{2}{|c|}{$\begin{array}{c}\mathrm{Ci} \\
(\mathrm{ppm})\end{array}$} & \multicolumn{2}{|c|}{$\begin{array}{c}\mathrm{Cs} \\
\left(\mathrm{mol} \mathrm{m}^{-2} \mathrm{~s}^{-1}\right)\end{array}$} \\
\hline & High N & Low $\mathrm{N}$ & High N & Low $\mathrm{N}$ & High N & Low N & High N & Low $N$ \\
\hline \multicolumn{9}{|c|}{ Vegetative stage } \\
\hline VC6153B & 18.34 & 13.57 & 0.450 & 0.450 & 281.9 & 288.6 & 1.141 & 1.141 \\
\hline GK 3 & 22.63 & 15.34 & 0.528 & 0.611 & 297.7 & 286.6 & 1.326 & 1.553 \\
\hline VC6144A & 16.59 & 8.22 & 0.524 & 0.343 & 260.9 & 311.2 & 1.309 & 0.878 \\
\hline PDM 54 & 15.26 & 8.93 & 0.631 & 0.427 & 324.8 & 323.6 & 1.595 & 1.094 \\
\hline IPSA 25 & 14.93 & 8.04 & 0.516 & 0.331 & 304.8 & 330.6 & 1.310 & 0.838 \\
\hline VO1443A-G & 12.92 & 8.65 & 0.331 & 0.289 & 330.6 & 310.3 & 0.838 & 0.740 \\
\hline $\operatorname{LSD}_{(0.05)}$ & 1.45 & 1.36 & 0.04 & 0.05 & 11.23 & 7.67 & 0.11 & 0.13 \\
\hline CV \% & 18.41 & 27.63 & 18.31 & 25.92 & 7.97 & 5.30 & 18.28 & 25.84 \\
\hline \multicolumn{9}{|c|}{ Flowering stage } \\
\hline VC6153B & 43.09 & 27.19 & 2.068 & 0.629 & 295.4 & 271.5 & 5.144 & 1.607 \\
\hline GK 3 & 43.75 & 32.75 & 2.409 & 0.877 & 296.8 & 271.6 & 3.996 & 2.233 \\
\hline VC6144A & 36.68 & 18.34 & 2.068 & 0.528 & 295.4 & 297.7 & 5.016 & 1.326 \\
\hline PDM 54 & 25.03 & 13.90 & 1.202 & 0.744 & 343.9 & 361.5 & 2.985 & 1.827 \\
\hline IPSA 25 & 24.17 & 14.12 & 0.877 & 0.392 & 302.6 & 289.6 & 2.171 & 0.970 \\
\hline VO1443A-G & 26.45 & 12.46 & 1.464 & 0.868 & 317.9 & 365.2 & 3.667 & 2.159 \\
\hline $\operatorname{LSD}_{(0.05)}$ & 3.91 & 3.56 & 0.25 & 0.08 & 8.26 & 18.40 & 0.49 & 0.21 \\
\hline CV \% & 25.84 & 38.35 & 32.12 & 26.15 & 5.70 & 12.67 & 27.49 & 26.44 \\
\hline \multicolumn{9}{|c|}{ Pod filling stage } \\
\hline VC6153B & 38.02 & 16.13 & 3.459 & 0.734 & 314.1 & 317.8 & 8.601 & 1.878 \\
\hline GK 3 & 41.42 & 22.73 & 1.289 & 0.910 & 274.0 & 325.0 & 3.209 & 2.263 \\
\hline VC6144A & 22.53 & 11.63 & 1.474 & 0.357 & 341.3 & 329.1 & 3.663 & 0.888 \\
\hline PDM 54 & 23.58 & 9.12 & 0.917 & 0.363 & 309.7 & 309.9 & 2.272 & 0.901 \\
\hline IPSA 25 & 18.84 & 10.45 & 0.740 & 0.582 & 301.3 & 259.7 & 1.867 & 1.447 \\
\hline VO1443A-G & 15.26 & 9.46 & 0.399 & 0.410 & 283.9 & 300.3 & 1.016 & 1.018 \\
\hline$\underline{\operatorname{LSD}_{(0.05)}}$ & 3.91 & 3.56 & 0.25 & 0.08 & 8.26 & 18.40 & 0.49 & 0.21 \\
\hline CV \% & 36.45 & 36.45 & 72.03 & 36.85 & 7.15 & 7.55 & 71.70 & 37.31 \\
\hline \multicolumn{9}{|c|}{ Maturity stage } \\
\hline VC6153B & 10.46 & 8.78 & 0.311 & 0.283 & 303.3 & 302.9 & 0.796 & 0.727 \\
\hline GK 3 & 18.61 & 11.22 & 0.362 & 0.497 & 257.1 & 295.8 & 0.926 & 1.265 \\
\hline VC6144A & 17.15 & 9.50 & 0.179 & 0.246 & 210.4 & 286.0 & 0.460 & 0.630 \\
\hline PDM 54 & 7.70 & 7.70 & 0.320 & 0.354 & 311.1 & 315.0 & 0.821 & 0.907 \\
\hline IPSA 25 & 7.16 & 6.77 & 0.220 & 1.112 & 299.5 & 395.7 & 0.565 & 2.756 \\
\hline V01443A-G & 9.50 & 6.07 & 0.266 & 0.220 & 279.9 & 299.5 & 0.682 & 0.565 \\
\hline$\underline{\operatorname{LSD}}_{(0.05)}$ & 2.10 & 0.81 & 0.03 & 0.15 & 16.26 & 17.25 & 0.07 & 0.36 \\
\hline $\mathrm{CV} \%$ & 38.10 & 20.74 & 22.46 & 68.36 & 12.51 & 11.64 & 22.32 & 66.29 \\
\hline
\end{tabular}

Notes: Pn- photosynthesis, $\mathrm{Cm}$ - Mesophyll conductance, $\mathrm{Ci}$ - Internal $\mathrm{CO}_{2}$ conc., Cs- Stomatal conductance

Maximum crop growth rate has been reported to be synchronous with the maximum leaf mass after flowering. Canopy development in mungbean was observed to be very slow till flowering stage by Kuo et al. 1978. Moreover Hamid et al. (1990) observed that at around maturity, the 
photosynthetic rate dropped to about $25 \%$ of its maximum. Excessive leaf area during later stages of growth was found to be detrimental to yield in mungbean. In the present study IPSA25 produced excessive leaf area but it had lower seed yield in low $\mathrm{N}$ level (Table 1). But higher photosynthetic rate does not guarantee higher seed yield (Curtis et al. 1969) as differential chlorophyll content makes differences in the photosynthetic rates in leaves, while the length of the growth cycle determines the amount of dry matter production and partitioning in plant parts.

\section{CONCLUSION}

In the present study, GK3 was found to have the highest photosynthesis rate as well as the highest productivity among the six genotypes followed by VC6144A, PDM54 and IPSA25 irrespective of N levels. This genotype may be selected as potential mungbean genotype for commercial cultivation both under low and high $\mathrm{N}$ environment.

\section{LiteratuRE Cited}

Babu, R.C., R. Sadassivan, N. Natarajratnam, S.R.S. Rangaswamy and S.R. Rangaswamy. 1985. Photosynthesis in relation to yield potential in blackgram. Maras Agric. J. 72, 152-155.

Berendse, F. 1994. Competition between plant populations at low and high nutrient supplies. Oikos. 71:253-260.

Biswas, D.K., M.M. Haque, A. Hamid and M.A. Rahman. 2001. Photosynthetic Gas Exchange Characteristics, Leaf Area and Dry Matter Accumulation of Two Blackgram Cultivars. Online Journal of Biological Sciences. 1(10), 951-954.

Bushby, H.V.A. and R.J. Lawn.1992. Accumulation and partitioning of nitrogen and dry matter by contrasting genotypes of mungbean (Vigna radiata (L.) Wilczek). Aust. J. Agric. Res. 43,16091628.

Clark, R.B. 1983. Plant genotypic differences in the uptake, translocation and use of mineral elements required for plant growth. Plant and Soil. 72, 175-196.

Curtis, P.E., W.L. Ogren and R.H. Hagmen.1969. Varietal effects in soybean photosynthesis and photorespiration. Crop Sci. 9, 323-327.

Hamid, A., F. Kubota, W. Agata and M. Morokuma. 1990. Photosynthesis, transpiration, dry matter accumulation and yield performance of mungbean plant in response to water stress. J. Fac. Agr. Kyushu Univ. 35, 81-92.

Islam, M.T. 1994. Eco-physiological studies on photosynthesis and dry matter production in mungbean (Vigna radiata (L.) Wilczek). Ph D Thesis. Kyushu University, Fukuoka, Japan.

Kubota, F. and A. Hamid. 1992. Comparative analysis of dry matter production and photosynthesis between mungbean (Vigna radiata (L.) Wilczek) and blackgram (Vigan mungo (L.) Hepper) grown in different light intensities. J. Fac. Agric., Kyushu Univ. 37, 71-80.

Kuo, C.G., L.J. Wang, A.C. Cheng and M.H. Chow. 1978. Physiological basis for mungbean yield improvement, pp. 205-209. In "Proceedings of 1st International Mungbean Symposium". Asian Vegetable Research and Development Centre, Shanhua, Taiwan.

Lawn, R.J. and C.S. Ahn. 1984. Mungbean. In R.J. Summerfield and E.H. Roberts (Eds) Grain Legume Crops. London, Collins, UK. pp. 584-623.

Mahon, J.D. 1990. Field evaluation in growth and nitrogen fixation in peas selected for high and low photosynthetic $\mathrm{CO}_{2}$ exchange. Can. J. Plant Sci. 30, 1093-1098.

Mahon, J.D. and S.L.A. Hobbs. 1987. Genetic control of photosynthesis in relation to pea (Pisum sativum L.) plants. In: Biggins, J. (Ed.). Progress in photosynthesis research. Martinus Nijhoff Publ., Dordrecht, The Netherlands, pp. 385-391. 
M. A. Hossain et al.

Srinivasan, P.S., R. Chandrababu, N. Natarajratnam and S.R.S. Rangaswamy. 1985. Leaf photosynthesis and yield potential in green gram (Vigna radiata (L.) Wilczek) cultivars. Trop Agric. (Trinidad) 62, 222-224.

Trung, B.C. and S.Yoshida.1982. Nutrient Uptake and its Distribution Patterns in Mungbean. Japan J. Trop. Agr. 26, 121-129.

Wallis, E.S. and D.E. Byth. 1988. Food Legumes: Slow runners forever? pp 548-557. In Mungbean: Proceedings of the Second International Symposium, AVRDC, Taiwan. 